\title{
TYPE II HYPOPHARYNGEAL DEFECT RECONSTRUCTION - A SINGLE INSTITUTION EXPERIENCE
}

\author{
Alan Pegan, Ivan Rašić, Andro Košec, Darko Solter, Davor Vagić, \\ Vladimir Bedeković and Mirko Ivkić
}

University of Zagreb, School of Medicine, Department of Otorhinolaryngology and Head and Neck Surgery, Sestre milosrdnice University Hospital Centre, Zagreb, Croatia

\begin{abstract}
SUMMARY - There are several options for hypopharyngeal reconstruction depending on defect size. Reconstructive options include primary closure, local flaps, regional axial flaps or regional intestinal flaps, and free flap transfer with skin or intestinal free flaps. The preferred method of reconstruction should minimize early postoperative complications that prolong hospital stay and/or become life threatening, ensure early restoration of function and decrease donor site morbidity. The purpose of this study was to evaluate functional outcomes of different flap reconstruction methods in type II hypopharyngeal defects. In this non-randomized retrospective cohort study, data on 31 (27 male and four female) patients were collected over a 10-year period of single institution type II hypopharyngeal defect reconstructions. The following measures of functional outcome were extracted from patient medical histories: postoperative complications (flap failure, fistula formation, donor site related complications), hospital stay in days and swallowing function after 14 days, 1 month and 6 months. There were nine patients in the radial forearm free flap (RFFF) reconstruction group, seven in the jejunum reconstruction group, and 15 in the gastric tube reconstruction group. In the RFFF group, three patients experienced flap failure; in the jejunal transfer group, no donor site morbidity was observed; whereas three patients from the gastric tube reconstruction group had minor abdominal skin wound dehiscence. Out of the 3 different reconstructive methods, RFFF was most likely to fail. The mean duration of hospital stay was 22.6 days, being shortest in the RFFF group. There were no significant differences in early postoperative swallowing function among the groups. The choice of flap used for hypopharynx reconstruction should be driven by donor site factors and functional outcomes. When assessing type II hypopharyngeal defect reconstruction results, the findings of this study suggest that free jejunal flaps and gastric tubes offer superior functional results in comparison with RFFFs.
\end{abstract}

Key words: Hypopharyngeal neoplasms; Reconstructive surgical procedures; Free tissue flaps; Enteral nutrition; Postoperative complications; Croatia

\section{Introduction}

The hypopharynx is the lower part of the pharynx, a tube-shaped organ spreading from the skull base to

Correspondence to: Alan Pegan, MD, Department of Otorhinolaryngology and Head and Neck Surgery, Sestre milosrdnice University Hospital Centre, Vinogradska c. 29, HR-10000 Zagreb, Croatia

E-mail: alanpegan13@gmail.com

Received March 31, 2017, accepted May 22, 2017 the cervical esophagus. It is often referred to as the aero-digestive crossing. The term does not only point out the anatomically complex relationship between the posteriorly situated oropharynx and the nose, mouth and larynx anteriorly, but also stresses its vital physiological functions, i.e. breathing, swallowing, and a uniquely human trait of speaking ${ }^{1}$.

The worldwide incidence of hypopharyngeal carcinoma is 1:100000, with the highest incidence in South America, India, and some parts of Europe ${ }^{2}$. According 
to the latest published data by the Croatian Institute of Public Health, there are approximately 120 new cases of hypopharyngeal carcinoma annually in Croatia, with an incidence of $2.6: 100000^{3}$. Nearly $90 \%$ of hypopharyngeal carcinomas are of squamous cell origin, arising from the epithelial layer, with the strongest risk factors being alcohol, tobacco and human papillomavirus related mutagenesis ${ }^{4}$.

Unlike laryngeal cancer patients, patients with hypopharyngeal carcinoma start experiencing initial symptoms late, due to local spread of the disease. Almost $70 \%$ of patients have stage III disease at presentation and $50 \%$ already have clinically visible cervical node metastatic disease present at the time of initial examination $^{1,5}$. A distinct feature of hypopharyngeal carcinoma is its tendency to spread underneath an intact mucosal layer, usually in caudal direction ${ }^{6,7} . \mathrm{Pa}^{-}$ tients with advanced stages of the disease (III and IV) are most often candidates for comprehensive oncologic treatment, combining extensive surgical ablation and reconstruction with adjuvant radiotherapy and chemotherapy treatment protocols.

According to Disa et al. ${ }^{8}$, hypopharyngeal ablation defects can be divided into five categories: type Ia partial defect of hypopharynx with laryngeal preservation: type $\mathrm{Ib}$ - partial defect of the hypopharynx with total laryngectomy; type II - total circumferential defects (total laryngectomy with total pharyngectomy) without resection of the tongue base; type III - total circumferential defects with extensive resection of the tongue base; and type IV - vertical hemipharyngolaryngectomy. Following the reconstruction ladder, there are several options for hypopharyngeal reconstruction depending on defect size. Reconstructive options include primary closure, local flaps, regional axial flaps (pectoralis major flap, deltopectoral flap) or regional intestinal flaps (gastric tube or colon transfer) and free flap transfer with skin (radial forearm free flap (RFFF), anterolateral thigh flap) or intestinal free flaps (jejunal flap or colon flap) $)^{9}$. The preferred method of reconstruction should minimize early postoperative complications that prolong hospital stay and/or become life threatening, ensure early restoration of function, and decrease donor site morbidity.

The purpose of this study was to evaluate functional outcomes of different flap reconstruction methods in type II hypopharyngeal defects.

\section{Patients and Methods}

This non-randomized retrospective cohort study with consecutive enrolment encompassed patient data collected over 10 years of single institution type II hypopharyngeal defect reconstructions. Thirty-one patients were eligible for inclusion in the study, and details of their medical histories were obtained from a computer database. Following radical surgical resection, all patients enrolled in the study had immediate reconstruction with gastric tube, RFFF or jejunal free flap. None of the patients had received preoperative treatment, and all patients underwent postoperative radiotherapy. All patients were followed up by a head and neck surgeon, oncologist and rehabilitation nurse for a minimum of one year. The patients gave their written informed consent for medical history data and intraoperative photograph usage.

Statistical analysis was performed using MedCalc software version 11.2.1 ${ }^{\odot}$ 1993-2010 (MedCalc Software bvba Software, Mariakerke, Belgium), employing standard descriptive statistics and frequency tabulation as indicated. Data on the $n=31$ cohort were expressed as ratios due to $n<100$. Associations between variables were assessed using the Spearman's rho correlation test, logistic regression and Kruskal-Wallis test for nonparametric independent samples. All tests of statistical significance were performed using a two-sided $5 \%$ type I error rate.

\section{Results}

The following measures of functional outcome were extracted from patient medical histories: postoperative complications (flap failure, fistula formation, donor site related complications), hospital stay in days, and swallowing function after 14 days, 1 month and 6 months. There were nine patients in the RFFF reconstruction group, seven patients in the jejunum reconstruction group, and 15 patients in the gastric tube reconstruction group. There were 27 male and four female patients.

\section{Postoperative surgical complications}

Postoperative surgical complications were classified into four major categories: no complications, flap failure, fistula formation, and donor site related complications. The early postoperative mortality rate in our 


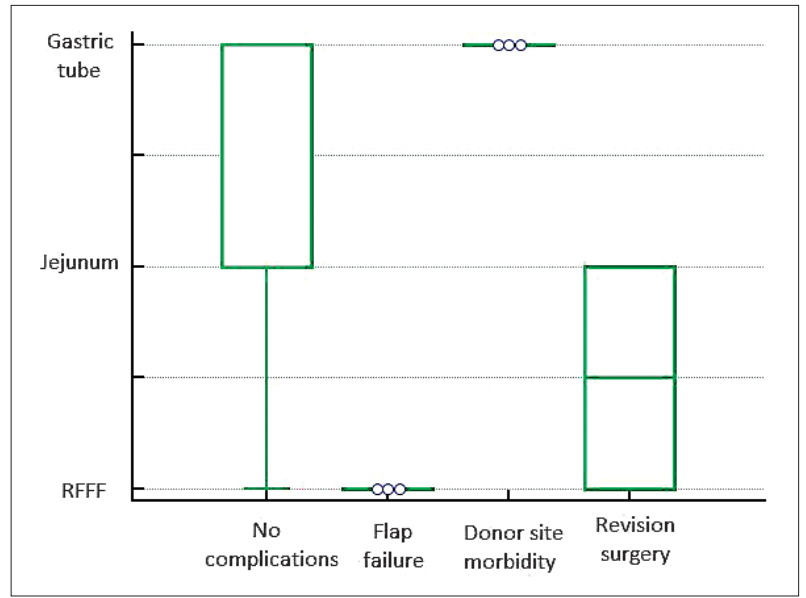

Fig. 1. Postoperative complications in different hypopharynx type II defect reconstructive methods.

series was $0 \%$. The majority of patients had no postoperative surgical complications (Fig. 1). Three patients in the RFFF group experienced flap failure and one experienced cutaneous fistula formation. In the jejunal transfer group, no donor site morbidity was observed, whereas in the gastric tube reconstruction group, three patients had minor abdominal skin wound dehiscence, all of them addressed with minor revision surgery. Out of the 3 different reconstructive methods, RFFF was most likely to fail (logistic regression, odds ratio 3.0, Hosmer-Lemeshow test, $\mathrm{p}=0.0041$ ).

\section{Swallowing function}

There were no significant differences in early postoperative swallowing function among the groups (Kruskal-Wallis test, $\mathrm{DF}=2, \mathrm{p}=0.87$ ). A significant difference was identified in swallowing function after 1 month, where gastric tube and jejunum transfer groups showed a marked difference in comparison with the RFFF group (Kruskal-Wallis test, $\mathrm{DF}=2, \mathrm{p}=0.031$ ) (Fig. 2). An even stronger correlation was found when analyzing swallowing function 6 months after surgery (Kruskal-Wallis test, DF=2, p=0.0053) (Fig. 3).

\section{Hospital days}

The mean hospital stay was 22.6 (range 14-42) days (Fig. 4). Hospital stay was shortest in the RFFF group and longest in the gastric tube group (Spearman's rank correlation test, $\mathrm{p}=0.02$ ).

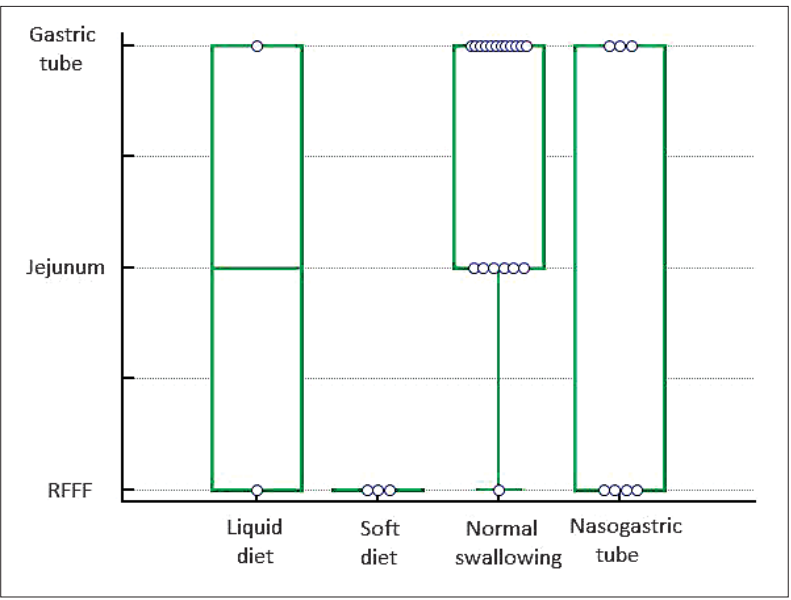

Fig. 2. Postoperative swallowing function after one month in various hypopharynx type II defect reconstructive methods.

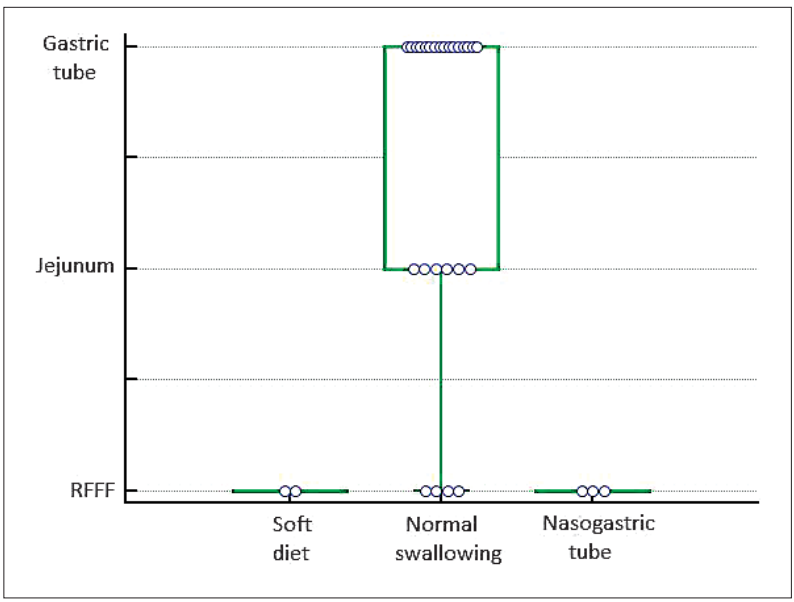

Fig. 3. Postoperative swallowing function after 6 months in various hypopharynx type II defect reconstructive methods.

\section{Discussion}

When total pharyngectomy is performed, special attention must be paid to reconstruction of the circular defect of the pharynx. Although there are numerous valid reconstructive options, the authors had taken closer look at three different techniques and compared their functional outcomes.

Gastric tube is a very appealing option for primary mode of reconstruction. A two-team approach with simultaneous dissection in the abdomen, mediastinum and neck shortens the operative time. Total esopha- 


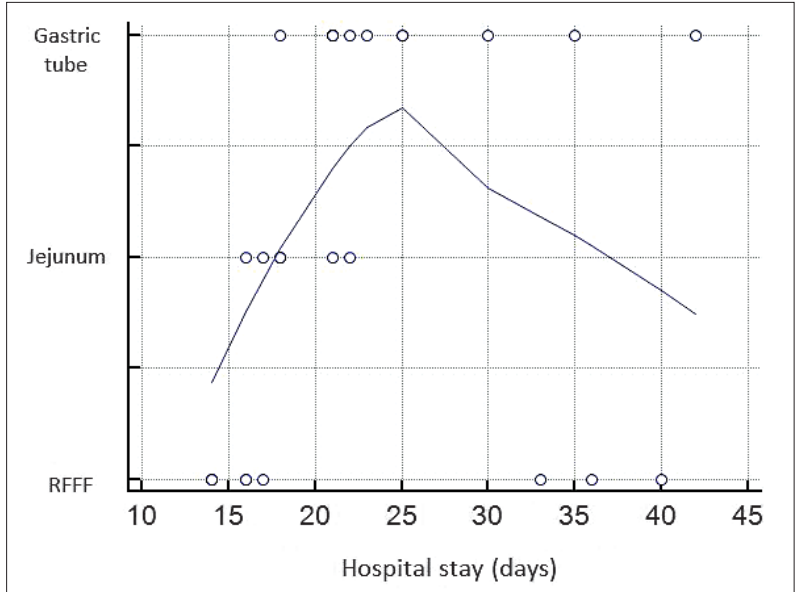

Fig. 4. Correlation of hospital stay length and hypopharynx type II defect reconstructive methods.

gectomy is performed through a transhiatal approach. Removal of the esophagus provides unlimited inferior dissection planes and lessens the surgeon's concern about distant submucosal nests of cancer spread ('skip lesions'). Superior resection can be as high as the naso- pharynx. This procedure allows the shortest hospitalization time of all forms of cervical esophageal reconstruction. The patient can usually be discharged 3 weeks after surgery, with successful deglutition. With only one visceral anastomosis (usually above the level at which the patient's oral secretions collect), postoperative infection, fistula and stenosis are markedly reduced. The shortcomings of the procedure are largely dictated by the extensive nature of the surgical invasion. With abdominal and thoracic, as well as head and neck entry required, some candidates for reconstruction may not be medically fit for this procedure. In many patients with carcinomas of the hypopharynx, a degree of pulmonary and cardiovascular compromise is expected ${ }^{10,11}$ (Fig. 5).

Radial forearm free flap offers a plentiful source of thin flexible tissue and long vascular pedicle representing an excellent choice for single stage reconstruction. RFFF flap is a good option in orohypopharynx, and cervical esophagus reconstruction up to upper thoracic aperture. Operating time is reduced owing to a twoteam approach. The fasciocutaneous flap can easily be
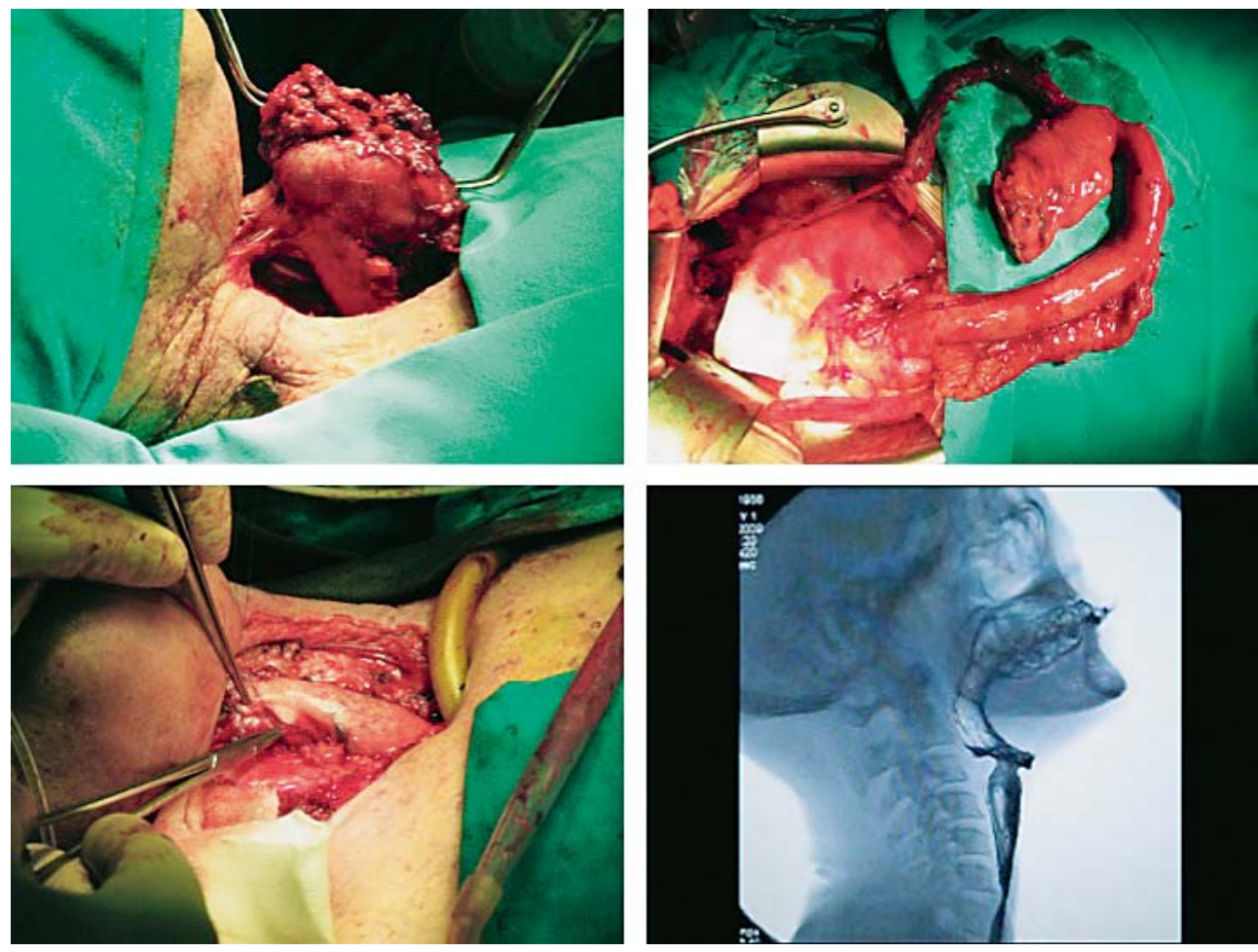

Fig. 5. A 62-year-old male patient with T4NOMO hypopharyngeal carcinoma and cervical esophagus involvement. Reconstruction with gastric pull up. The patient restored adequate deglutition three weeks postoperatively. 

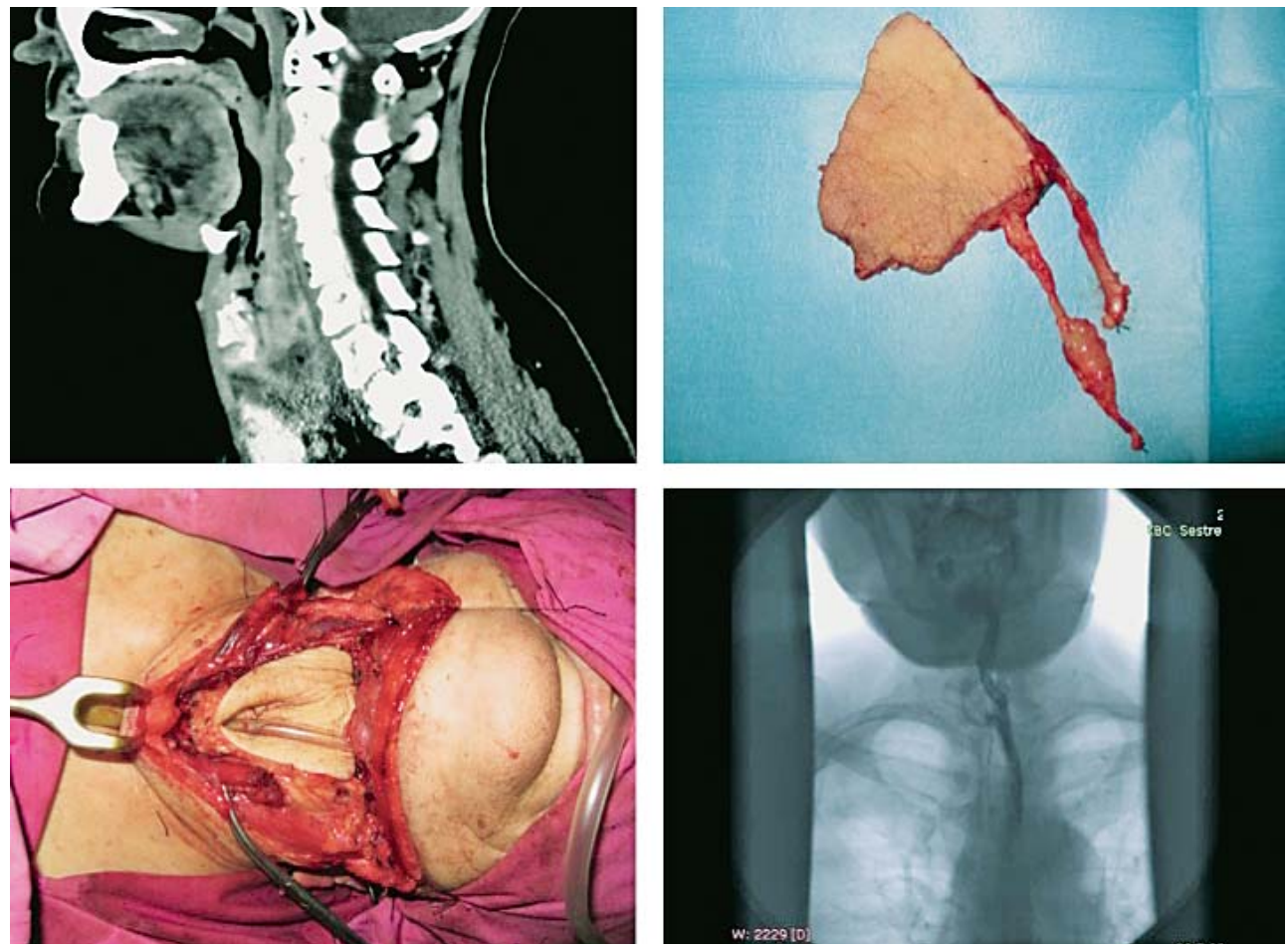

Fig. 6. A 64-year-old female patient with T3N2cMO cancer of the hypopharynx and circumferential defect following total laryngopharyngectomy. Reconstruction was performed with tubed 'tongue and groove' radial forearm free flap design on distal extension.
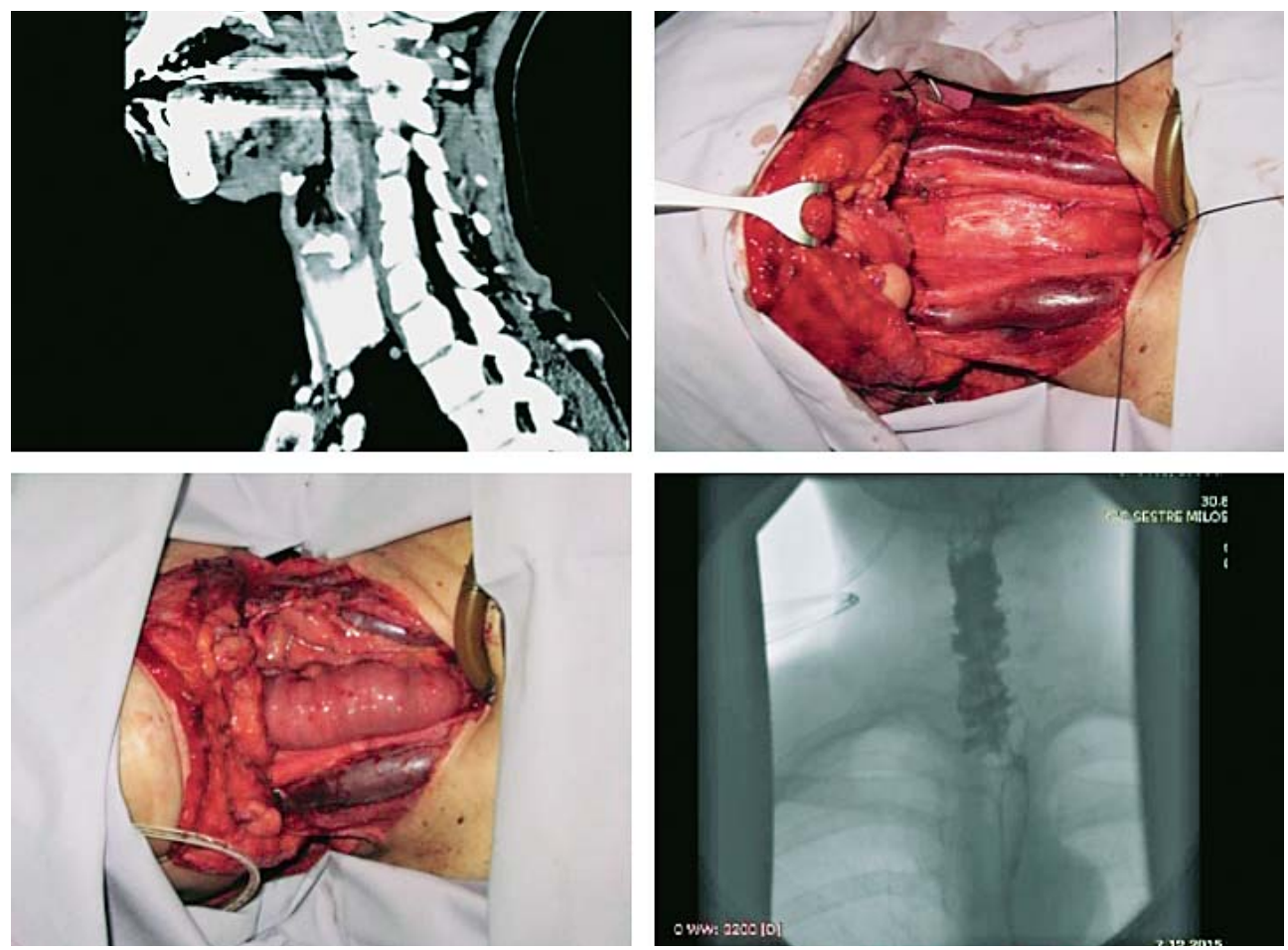

Fig. 7. A 48-year-old female patient with T4NOMO postcricoid cancer, circumferential defect following total laryngopharyngectomy. Reconstruction was performed with jejunal free flap. 
tubed. However, the vertical suture made close to the cylinder can add another point of potential weakness and dehiscence (Fig. 6). There is also low donor site morbidity, primarily because this technique eliminates the possibility of abdominal or thoracic complications with intestinal flaps. It is a suitable option for patients who are not candidates for abdominal procedures ${ }^{12}$.

Jejunal free flap provides a moist, mucosa-lined tube for single stage reconstruction. It is an excellent size match for the cervical esophagus and is ideally suited for circumferential defects because of its preexisting tube shape. As with gastric tube procedures, it requires a two-team approach by head and neck and gastric surgeons. An intestinal segment up to $20 \mathrm{~cm}$ can be harvested. Transillumination of the bowel is performed to allow identification of the best arteriovenous pedicle, which is confirmed by palpation of the vessels through the mesentery. A major drawback of this flap is its low tolerance to hypoxia, so immediate vascular anastomosis should be done prior to final suturing the flap into the defect (Fig. 7). As with RFFF, one can reconstruct defects ranging from the oropharynx down to the upper thoracic aperture ${ }^{1}$.

Many authors discuss early postoperative mortality rates. In a study of 209 patients with hypopharyngeal and cervical esophagus cancer, Triboulet et al. compared patients with stomach interposition, free jejunal flap, and pharyngocolic anastomosis. The authors found early mortality rate of $4.8 \%$, and significant complications occurred in $38.3 \%$ of cases ${ }^{11}$. Similar reconstruction methods were compared in the study by Pesko et al. (40 patients), and the early postoperative mortality rate was $13 \%{ }^{13}$. In the study by Denewer et al. (142 patients), pectoralis major flap, free jejunal flap, augmented colon bypass, gastric pull up and gastric tube were compared for pharyngoesophageal reconstruction and early postoperative mortality rate was $10.6 \%{ }^{14}$. In our study, the early postoperative mortality rate was $0 \%$. Although this is a very encouraging result for our team, it could be because patients enrolled in the study did not have any treatment prior to the surgery.

Unfortunately, we did have a high flap failure rate in the RFFF group in comparison to other studies ${ }^{15}$. The reasons leading to this could be early fistula formation and not using salivary bypasses advocated by some authors ${ }^{10}$. This could explain the $0 \%$ of flap failures in the other two groups that used preexisting tube shaped organs. Another possible problem could be found in the fact that patients in the RFFF group had a worse performance status ${ }^{16}$ in comparison to the other two groups, which was not shown in the results. Donor site morbidity was low in all groups, which is consistent with data found in the literature ${ }^{17}$.

The mean hospital stay as described in the literature highly varies from 12 to 29 days $^{10,13}$. The mean hospital stay in our series was 22.6 with the shortest stay being in the RFFF group.

The type (normal, soft, fluid) of patient diet defined swallowing function in our study. After 6 months, 90\% of patients had a fully restored oral diet, which was better functional outcome than previously noted ${ }^{13,16}$. All patients in the jejunum and gastric tube groups had normal deglutition after 6 months. In the RFFF group, one of the three patients with flap failure underwent revision surgery 6 months after initial treatment, with normal deglutition achieved post-revision, whereas the other two patients were treated with gastrostoma formation and enteral feeding. Studies have shown that around $20 \%$ of patients who had RFFF used for primary reconstruction develop strictures at the point of distal anastomosis ${ }^{18,19}$. The surgical philosophy in our institution was to use a 'tongue and groove' RFFF design in all patients, thus minimizing the risk of stricture at distal anastomosis ${ }^{20}$. At distal enteric anastomosis, a two-centimeter long triangular skin extension was incorporated into the end of the flap and sutured to the cervical esophageal remnant. The goal of this procedure was to break up the circumferential scar that promotes development of the stricture ${ }^{21}$.

More than $60 \%$ of patients in the RFFF group achieved normal deglutition 6 months after surgery, which is consistent with the results reported by Lopez et $a l .{ }^{12}$. Early postoperative deglutition function measured after 14 days showed no statistical difference among the groups. It should be noted that all patients in the jejunum transfer group were able to sustain oral fluid intake 14 days after surgery. At one month after surgery, the jejunum and gastric tube groups showed superior results in achieving normal deglutition compared to the RFFF group.

\section{Conclusion}

The choice of flap used for hypopharynx reconstruction should be driven by donor site factors and functional outcomes. Reconstructive aims need to be 
individualized with respect to morbidity, previously noted disease outcomes, and patient performance status. This study included a homogeneous patient population regarding defect size and type (only type II defects), which is rarely the case in published literature $^{10,13,16}$. When assessing type II hypopharyngeal defect reconstruction results, the findings of this study suggest that free jejunal flaps and gastric tubes offer superior functional results in comparison with RFFFs.

\section{References}

1. Uppaluri R,Sunwoo JB. Neoplasms of the hypopharynx and cervical oesophagus. In: Cummings CW, editor. Cummings Otolaryngology and Head and Neck Surgery. Philadelphia: Mosby, Inc.; 2005.

2. Popescu CR, Bertesteanu SVG, Mirea D, Grigore R, Ionescu D, Popescu B. The epidemiology of hypopharynx and cervical esophagus cancer. J Med Life. 2010;3:396-401.

3. Hrvatski zavod za javno zdravstvo. Registar za rak. Incidencija raka u Hrvatskoj 2013. Bilten br. 38 Zagreb: Hrvatski zavod za javno zdravstvo; 2015; p. 18-22. (in Croatian)

4. http://emedicine.medscape.com/article/1375268-overview\#a1.

5. Hoffman HT, Karnell LA, Shah JP, Ariyan S, Brown GS, Fee WE, et al. Hypopharyngeal cancer patient care evaluation. Laryngoscope 1997;107:1005-17.

6. Ho CM, Ho CM, Ng WF, Lam KH, Wei WJ, Yuen AP. Submucosal tumor extension in hypopharyngeal cancer. Arch Otolaryngol Head Neck Surg. 1997;123;959-65.

7. Wei WI. Current status of pharyngolaryngo-esophagectomy and pharyngogastric anastomosis. Head Neck. 1998;20:240-4.

8. Disa JJ, Pusic AL, Hidalgo DA, Cordeiro PG. Microvascular reconstruction of the hypopharynx: defect classification, treatment algorithm, and functional outcome based on 165 consecutive cases. Plast Reconstr Surg. 2003;111:652-60.

9. Kim Evans KF, Mardini S, Salgado CJ, Chen H-C. Esophagus and hypopharyngeal reconstruction. Semin Plast Surg. 2010; 24:219-26. doi: 10.1055/s-0030-1255339

10. Ong GB, Lee TC. Pharyngogastric anastomosis after oesophago-pharyngectomy for carcinoma of the hypopharynx and cervical oesophagus. Br J Surg.1960;48:193-200.
11. Triboulet JP, Mariette C, Chevalier D, Amrouni H. Surgical management of carcinoma of the hypopharynx and cervical esophagus: analysis of 209 cases. Arch Surg. 2001;136:1164-70.

12. López F, Obeso S, Camporro D, Fueyo A, Suárez C, Llorente JL. Outcomes following pharyngolaryngectomy with fasciocutaneous free flap reconstruction and salivary bypass tube. Laryngoscope. 2013;123:591-6.

doi: 10.1002/lary.23695

13. Pesko P, Sabljak P, Bjelovic M, Stojakov D, Simic A, Nenadic $\mathrm{B}$, et al. Surgical treatment and clinical course of patients with hypopharyngeal carcinoma. DisEsophagus 2006;19:248-53.

14. Denewer A, Khater A, Hafez MT, Hussein O, Roshdy S, Shahatto $\mathrm{F}$, et al. Pharyngoesophageal reconstruction after resection of hypopharyngeal carcinoma: a new algorithm after analysis of 142 cases. World J Surg Oncol. 2014;12:182. doi: 10.1186/1477-7819-12-182

15. Andrades P, Pehler SF, Baranano CF, Magnuson JS, Carroll WR, Rosenthal EL. Fistula analysis after radial forearm free flap reconstruction of hypopharyngeal defects. Laryngoscope. 2008;118:1157-63. doi: 10.1097/MLG.0b013e31816f695a

16. Oken MM, Creech RH, Tormey DC, Horton J, Davis TE, McFadden ET, et al. Toxicity and response criteria of the Eastern Cooperative Oncology Group. Am J Clin Oncol. 1982; 5:649-55.

17. van der Putten L, Spasiano R, de Bree R, Bertino G, Leemans $\mathrm{CR}$, Benazzo M. Flap reconstruction of the hypopharynx: a defect oriented approach. Acta Otorhinolaryngol Ital. 2012; 32:288-96.

18. Azizzadeh B, Yafai S, Rawnsley JD, Abemayor E, Sercarz JA, Calcaterra TC. Radial forearm free flap pharyngoesophageal reconstruction. Laryngoscope. 2001;111;807-10. doi: 10.1097/00005537-200105000-00010

19. Clark JR, Gilbert R, Irish J, Brown D, Neligan P, Gullane PJ. Morbidity after flap reconstruction of hypopharyngeal defects. Laryngoscope. 2006;116:173-81. doi: 10.1097/01.mlg.0000191459.40059.fd

20. Harii K, Ebihara S, Ono I, Saito H, Terui S, Takato T. Pharyngoesophageal reconstruction using a fabricated forearm free flap. Plast Reconstr Surg. 1985;75:463-76.

21. Urken ML. Multidisciplinary Head and Neck Reconstruction: A Defect-Oriented Approach. Philadelphia: Lippincott Williams and Wilkins; 2010. 
Sažetak

\title{
ULOGA SLOBODNIH REŽNJEVA U REKONSTRUKCIJI DEFEKTA TIPA II HIPOFARINKSA
}

\author{
A. Pegan, I. Rašić, A. Košec, D. Solter, D. Vagić, V. Bedeković i M. Ivkić
}

Postoji niz metoda za rekonstrukciju hipofarinksa, a odabir ovisi o veličini defekta sluznice. Metode rekonstrukcije uključuju primarno zatvaranje, lokalne režnjeve, regionalne aksijalne režnjeve, regionalne režnjeve probavnog sustava i slobodne režnjeve koji sadrže kožu ili sluznicu probavnog sustava. Optimalna metoda rekonstrukcije trebala bi biti praćena minimalnim poslijeoperacijskim komplikacijama koje ako nastaju produljuju broj dana provedenih u bolnici, i trebala bi uključivati brz oporavak funkcije. Cilj ove nerandomizirane retrospektivne studije bio je prikazati rezultate rekonstrukcija bolesnika s defektom hipofarinksa tipa II. U razdobolju od 10 godina u Klinici za otorinolaringologiju i kirurgiju glave i vrata, KBC "Sestre milosrdnice" operiran je 31 bolesnik (27 muškaraca i četiri žene). Za procjenu ishoda rekonstrukcije upotrebljene su sljedeće mjere: rane poslijeoperacijske komplikacije (propadanje režnja, postojanje fistule, komplikacije donorskog mjesta), duljina boravka u bolnici i procjena funkcije gutanja nakon 14 dana, jednog mjeseca i šest mjeseci. Bolesnici su podijeljeni u sljedeće skupine: devet bolesnika s radijalnim režnjem (RFFF), sedam bolesnika s režnjem jejunuma i 15 bolesnika s tzv. gastric tube rekonstrukcijom. U tri bolesnika skupine RFFF režanj je propao; u skupini s režnjem jejunuma nije bilo komplikacija donorskog mjesta, dok su u skupini s gastric tube rekonstrukcijom tri bolesnika imala manju dehiscijenciju rane trbušnog zida. Od tri uspoređivane rekonstrukcijske metode bolesnici u skupini RFFF imali su najveći broj komplikacija. Prosječna duljina boravka u bolnici iznosila je 22,6 dana, s najkraćim boravkom u skupini RFFF. Nije nađeno razlika u ranoj gluticijskoj funkciji između uspoređivanih skupina. Odabir pojedine metode rekonstrukcije trebao bi ovisiti o opsegu resekcije, općem stanju bolesnika, donorskom mjestu i očekivanoj funkciji. Naši rezultati upućuju na superiornost rekonstrukcije upotrebom "jejunalnog režnja” i gastric tube rekonstrukcije u usporedbi s radijalnim režnjem.

Ključne riječi: Hipofaringealni tumori; Rekonstruktioni kirurški postupci; Slobodni tkioni režnjevi; Enteralna prebrana; Poslijeoperacijske komplikacije; Hrvatska 